(ㄱ Т. Ю. Киричок, д-р техн. наук, проф., В. А. Баглай, аспірант, КПІ ім. Ігоря Сікорського, Київ, Україна

\title{
СИСТЕМА ФОРМУВАННЯ ТИРАЖОСТІЙКОСТІ ФОРМ ІНТАГЛІОДРУКУ
}

Сучасний спосіб виготовлення форм інтагліодруку технологія прямого лазерного гравіювання (DLE - Direct Laser Engraving) має переваги та технологічні можливості порівняно з традиційною технологією травлення. Однак, особливості обробки матеріалів форм лазером і подальшого нанесення захисного нітрид-хромового покриття вакуумним напиленням (PVD) можуть викликати зниження тиражостійкості форм порівняно із традиційними технологіями виготовлення форм. Тому технологія прямого лазерного гравіювання з подальшим нанесенням захисного нітрид-хромового покриття PVD потребує удосконалення режимів гравіювання, оброблення форм після видалення напливів і PVD.

Ключові слова: інтагліодрук; пряме лазерне гравіювання; друкувальні елементи; гравійовані штрихи; тиражостійкість; покриття нітриду хрому; латунь; вакуумне напилення.

Постановка проблеми

Сучасний спосіб виготовлення форм інтагліодруку - технологія прямого лазерного гравіювання (DLE - Direct Laser Engraving) має переваги та технологічні можливості порівняно з традиційною технологією травлення. Однак, особливості обробки матеріалів форм лазером і подальшого нанесення захисного нітрид-хромового покриття вакуумним напиленням (PVD) можуть викликати зниження тиражостійкості форм порівняно із традиційними технологіями виготовлення форм. Тому технологія прямого лазерного гравіювання з подальшим нанесенням захисного нітрид- хромового покриття PVD потребує удосконалення режимів оброблення форм і PVD.

\section{Мета роботи}

Встановлення особливостей інтагліодруку, що можуть спричиняти руйнацію і, як наслідок, зниження тиражостійкості форм, визначення факторів формування тиражостійкості форм інтагліодруку та створення на цій основі системи її формування.

\section{Результати проведених} досліджень

Особливості інтагліодруку,

що можуть спричиняти

руйнацію форм

Процес інтагліодруку має особливості. Надзвичайно високий 
тиск у зоні контакту формного та друкарського циліндрів (лінійне навантаження між формним і друкарським циліндрами у процесі інтагліодруку становить до 1000 кH/м [1-4], є аналогом каландрування паперу в процесі його виготовлення [2, 3] та спричиняє, як значне ущільнення основи банкнот, так і $є$ основною причиною руйнування за умови тривалого використання форм інтагліодруку.

Як було встановлено в попередніх дослідженнях, рельєф інтагліодруку, котрий складається з фарбового шару та підфарбового рельєфу, утворюється як результат спільної дії тиску в друкарському контакті, який прикладається дещо відмінно до різних ділянок паперу, та підвищеної до 80-82 C температури формного циліндра та нагрітої до цієї ж температури фарби. Процес накочування фарби на друкарську форму включає етапи: 1) фарба в'язкістю 0,1-10 Па.с за температури $25^{\circ} \mathrm{C}$ та швидко-

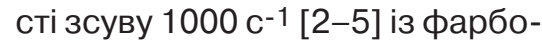
вого ящика, де підтримується температура $17-21^{\circ} \mathrm{C}$, за допомогою накочувальних і розкочувальних валиків переноситься на шаблонні циліндри; 2) із шаблонних циліндрів, розігрітих до температури приблизно $34^{\circ} \mathrm{C}$, фарба через збірний циліндр із температурою $36^{\circ} \mathrm{C}$ передається на формний циліндр, розігрітий до 80-82 С, що містить одну або більше гравійованих друкарських форм.

Більшість фарб для металографічного методу друку використовуються сьогодні, як і раніше, на основі алкідних смол у кількості приблизно 15-50 \% від ваги фарби, які мають ступінь нейтралізації між 10 \% і 35 \% і кислотне число 30-110. Фарби пастоподібні, можуть містити ненасичені масляні компоненти у кількості 5-15\% ваги, аніонну та неіоногенну поверхнево-активну речовину в кількості 0,5-12 \% ваги, і органічну багатофункціональну основу в кількості 0,5-5 \% ваги, відібрану з групи, що складається з амінів спирту, поліетилену та органічної основи, що має точку кипіння 70-150 [5-8]. У більшості випадків органічною основою, яка відповідає за зміну реологічних властивостей фарби при зміні температурних режимів, є віск [6-8].

Основною перевагою фарб на основі алкідних смол є хороше затвердіння, що забезпечується механізмом окислювальної полімеризації, яка призводить до утворення хороших показників фізичного та хімічного опорів надрукованої та висушеної продукції [6]. Алкідні смоли окислювальної полімеризації мають головний недолік, визначений повільним висиханням, що призводить до зниження темпів виробництва та відмарування фарби на зворотний бік наступного аркуша у стосі, а також необхідність використання екологічно небезпечних органічних розчинників (VOC - летючі органічні сполуки) [7]. У результаті поширеності саме таких фарб друкарські машини в більшості випадків оснащені фарбовими системами, гумотканинними полотнами та стиральними циліндрами, стійкими до дії алкідної і вуглеводневої хімії традиційних металографічних друкарських фарб $[9,10]$. 
Крім того, форма, встановлена на формному циліндрі, задля очищення пробільних елементів від фарби під час кожного оберту входить у трибологічний контакт зі стиральним валом, який, до того ж може містити на поверхні залишки змивного розчину, що омиває стиральний вал після кожного контакту з формним циліндром. Очищення стирального вала зазвичай здійснюється розбавленим водою розчином каустичної соди, що містить 0,1-1 \% $\mathrm{NaOH}, 0,5$ \% сульфованої касторової олії, інших поверхнево-активних речовин, чи навіть чистою водою [2, 3].

Гравійовані штрихи форми інтагліодруку зазвичай мають глибину 20-100 мкм, ширина їх визначається дизайном банкноти та перебуває приблизно в таких же межах.

у попередніх дослідженнях проведено аналіз паралельного до напрямку руху перерізу формного та друкарського циліндрів у місці найбільшого зближення показує, що через деформування паперу та декеля, а також через великий тиск утворюється ділянка, котра, власне, і є реальним друкарським контактом [11]. Встановлено, що під час друку різні ділянки паперу, форми та декеля в друкарському контакті зазнають різного тиску та температурних впливів [2, 3]. Розмір друкарського контакту було оцінено з таких міркувань: тиск у друкарському контакті викликає ущільнення волокон основи, через що навіть на 2-3 мкм зменшується товщина задрукованого паперу поза межами друкувальних елементів - гравійованих штрихів форми [11]. Після зняття тиску відбувається декомпресія волокон паперу, тому, очевидно, в момент друкарського контакту стиснення паперу $є$ ще вищим. Таким чином, мінімальний теоретичний розмір контакту, з урахуванням діаметрів циліндрів (840 мм на машинах Super-Orlof-Intaglio) та зниження товщини паперу складе 4-6 мкм, а реальний значно більше. На ділянки паперу, котрі контактують із пробільними елементами форми, тиск впливає протягом всього часу друкарського контакту $t_{\text {пір }}$, сприяючи ущільненню волокон. Дещо інший за часом вплив тиску на ділянки паперу, котрі контактують із друкувальними елементами.

Гравійовані штрихи форм інтагліодруку в результаті перенесення фарби зі збірного циліндра заповнюються фарбою не на повну глибину [12], через що фарба в штриху має можливість зміщуватися. Через це в місці друкувального елементу волокна паперу деформуються, вигинаючись під дією тиску всередину штриха до моменту контакту із фарбою. Таким чином, відбувається формування підфарбового рельєфу, який у попередніх дослідженнях, як визначено, має висоту 10-20 мкм (для досліджуваних розмірів гравійованих штрихів), що складає 40-60 \% від висоти всього фарбового рельєфу інтагліодруку [13]. При цьому, тиск у друкарському контакті на друкувальні елементи $\epsilon$, очевидно, меншим, ніж на пробільні, однак, друкувальні елементи під дією тиску деформуються в напрямку до друкарського циліндру, зазнаючи деформацій розтягнення, тоді як пробільні елементи зазнають 
деформацій стиснення. Переважно вид деформацій, яких зазнають бічні грані гравійованих штрихів, залежить від профілю штрихів (трапецієподібні чи прямокутні). Однак, зрозуміло, що напруження, які виникають у формах як через динамічні навантаження під час роботи, так і через композиційний їх характер (наявність основи та захисного покриття) спричиняють порушення адгезії захисного покриття до основи i, в подальшому, до поступового руйнування форми.

Отже, ретельне вивчення процесів інтагліодрукування дозволяє зробити висновок, що руйнування форм інтагліодруку спричиняють фактори різного характеру:

1) Механічні фактори - насамперед, надзвичайно високий тиск у друкарському контакті, котрий діє неоднаково на друкувальні та пробільні елементи форм, спричиняючи деформації стиснення і розтягування на різних ділянках форми; трибологічний контакт зі стиральним валом, що викликає поступове руйнування захисного покриття; напруги, які $€$ характерними для багатошарових структур (захисне нітрид-хромове покриття-латунна основа); знеміцнення приповерхневого шару латунної основи під час лазерного оброблення.

2) Хімічні фактори - постійний контакт форми з хімічними сполуками рідкого та газоподібного виду - фарбами та змивними розчинами, що сприяють окислювальній руйнації.

3) Тепловий вплив - постійний температурний градієнт через контакт з нагрітою фарбою.

Однак, слід зазначити, що всі ці фактори, сприяючи поступово- му руйнуванню форм інтагліодруку, є практично такими, що неможливо корегувати, а лише варто ураховувати під час виготовлення форм. Ключовим для забезпечення високої тиражостійкості форм інтагліодруку, отриманих прямим лазерним гравіюванням, є забезпечення високої адгезійної міцності захисного нітрід-хромового покриття.

\section{Фактори формування \\ тиражостійкості форм \\ інтагліодруку}

На основі аналізу літературних джерел і аналізу процесу інтагліодруку виділено дві основні групи факторів, що впливають на тиражостійкість форм інтагліодруку.

Першою групою є параметри процесу друкування (тиск у друкарському контакті, швидкість друку, склад змивного розчину, склад фарби, притискання стирального вала, параметри декеля, параметри паперу), котрі здійснюють значний вплив і, власне, спричиняють поступове руйнування форм інтагліодруку (рис.). Ці фактори потребують урахування під час, наприклад, математичного моделювання чи штучного зношування форм у дослідженнях. Однак, вони практично незмінні, оскільки визначаються особливостями способу друку чи технологічними регламентами.

Другою групою факторів є параметри форми інтагліодруку DLE:

- стан поверхні форми після процесу DLE (шорсткість стінок штриха та твердість приповерхневого шару);

- спосіб очищення форми від напливів DLE до завантажен- 
ня у вакуумну камеру та безпосередньо режими травлення в камері;

- товщина захисного покриття нітриду хрому;

- склад аргоново-азотної суміші в камері під час процесу PVD;

- склад (чистота) хромової мішені;

- параметри штрихів (їх ширина, довжина, глибина, напрямок відносно переважної орієнтації волокон паперу, відстань між штрихами, вид профілю (V-подібний, трапецієподібний, прямокутний, U-подібний), симетричність профілю (симетричний, асиметричний).

Частина вхідних факторів (ширина, довжина, вид лінії (пряма/ крива), напрямок відносно переважної орієнтації волокон паперу, відстань між штрихами) визначається дизайном банкнот і не підлягає варіюванню. Ці фактори встановлені під час аналізу зображень інтагліодруку банкнот різних номіналів і можуть бути враховані під час розроблення модельних форм для подальших досліджень.

Чистота мішені приймається за ідеальну і не підлягає варіюванню: мішені поставляються й утилізуються виробником обладнання. Хоча підвищення адгезії покриття за рахунок використання модифікованих легованих мішеней може бути об'єктом подальших перспективних досліджень.

Стан поверхні форми після процесу DLE (шорсткість стінок штриха та твердість приповерхневого шару) має бути об'єктом вивчення і урахування задля з'ясування взаємозв'язку з парамет- рами штрихів форми і адгезією захисного покриття. Це доцільно зробити в подальших перспективних дослідженнях.

Як першочергові доцільно виокремити дослідження таких факторів: спосіб очищення форми від напливів DLE до завантаження у вакуумну камеру та безпосередньо режими травлення в камері (тривалість (збільшена/ рекомендована), напруга, що прикладається до форми, вид розряду); товщина захисного покриття нітриду хрому (у межах рекомендованих виробником (2 мкм, 4 мкм, 6 мкм). Також необхідно встановити їх зв'язок з тими параметрами штрихів, які можуть варіюватися - вид профілю (трапецієподібний, прямокутний), симетричність профілю (симетричний, асиметричний), кут нахилу стінок штриха, глибина штриха (у певних межах).

Всі фактори, що можуть варіюватися, позначено на рис. півжирним шрифтом.

Оскільки забезпечення тиражостійкості форм під час інтагліодруку є складним багатоаспектним процесом, що характеризується різноманітними чинниками, якими можна керувати, великою кількістю складних кореляційних зв'язків між ними, дослідження залежності тиражостійкості форм інтагліодруку потребує використання багатофакторного експерименту.

Зв'язок між вхідними та вихідними параметрами має вигляд функції відгуку типу $\mathrm{Y}=\varphi\left(\mathrm{x}_{1}\right.$, $\left.\mathrm{x}_{2}, \ldots, \mathrm{x}_{\mathrm{k}}\right)$, де $\mathrm{x}_{1}, \mathrm{x}_{2}, . . \mathrm{x}_{\mathrm{k}}$ - керовані фактори, що впливають на відгук системи, які можна фіксувати на певному рівні або варіювати 


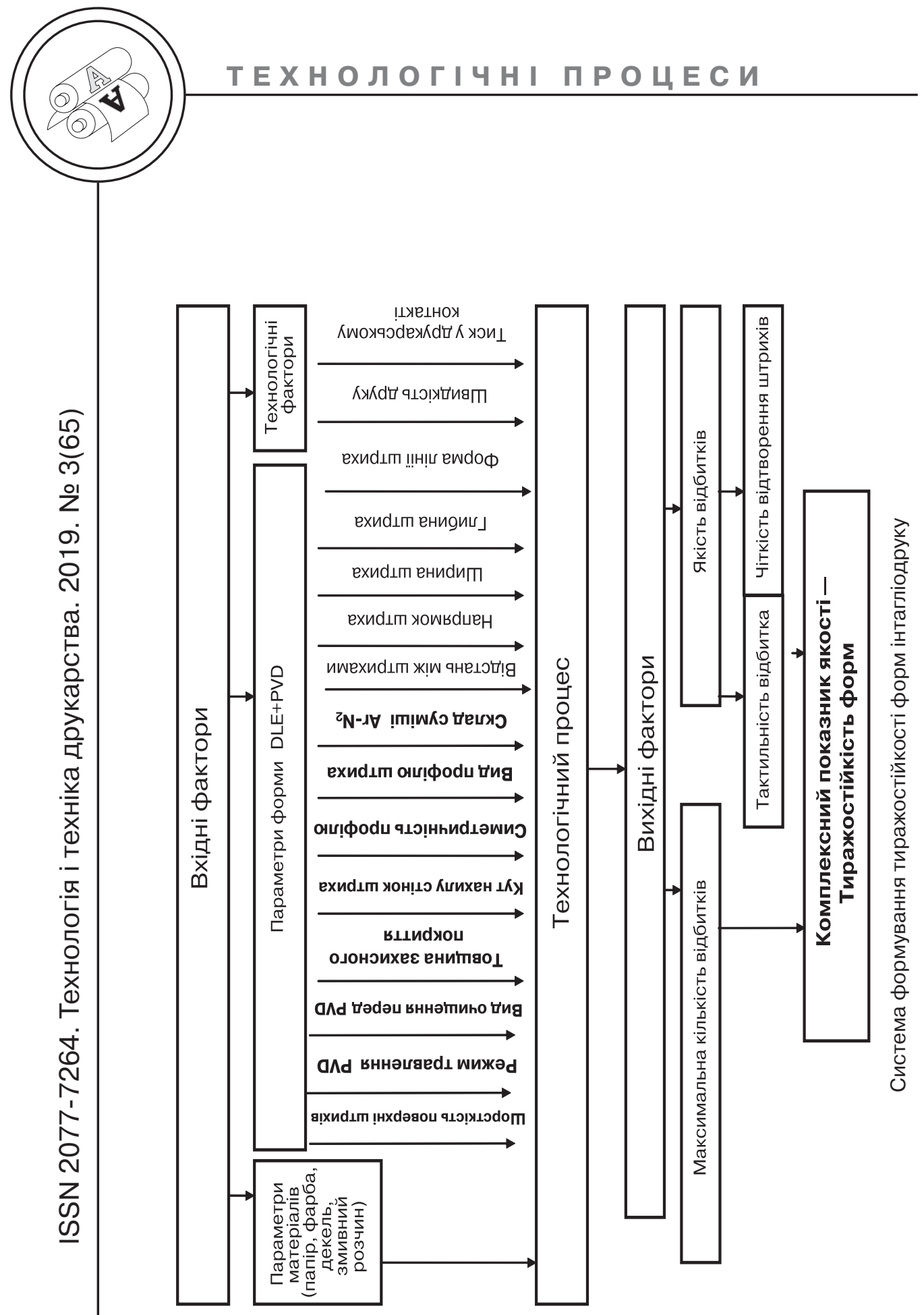


в процесі експерименту (наприклад, вид очищення форми, товщина захисного покриття, глибина, вид і симетричність профілю).

Вихідні параметри можуть бути використані як критерії оптимізації.

Фактично, єдиним вихідним параметром $є$ тиражостійкість форм - повна кількість задовільної якості відбитків, які можна отримати з однієї друкарської форми [14]. Враховуючи, що значною мірою тиражостійкість визначається адгезійною міцністю покриття, варто визначати їі показники та чинники (напруги на окремих ділянках форм, міцність покриття та приповерхневого шару, мікроструктуру перерізу покриття та приповерхневого шару) як до зношування форми, так і після нього, для чого передбачити виготовлення кількох ідентичних за параметрами форм, а також нікелевої форми із захисним PVD-покриттям.

Функцією відгуку є тиражостійкість форм інтагліодруку, що визначається комплексним показником якості I шляхом формування функції корисності на основі часткових показників якості - чіткості відтворення штрихів на відбитку у 1 та тактильності відбитка у2, наприклад за допомогою адитивної згортки показників [8].

Вибір незалежних факторів проведено, виходячи з таких передумов. Фактори, які впливають на якість відбитків інтагліодруку, повинні мати певну область ви- значення, відповідати таким вимогам: керованість, однозначність, сумісність між собою, можливість задання з достатньою для кількісного аналізу точністю, величина їх має залишатися сталою в процесі експерименту та впливати на залежні фактори. Незалежними факторами, які відповідають цим вимогам, у нашому випадку можуть бути: тиск у друкарському контакті (P) $-\mathrm{x}_{1}$, (у.о.); глибина штриха (h) $-\mathrm{x}_{2}$, мкм; кут нахилу бокових стінок штриха $(\delta)-x_{3}$, град.; вид профілю - $\mathrm{x}_{4}$.

\section{Висновки}

Виділено три основні групи факторів, які впливають на тиражостійкість форм інтагліодруку: параметри процесу DLE (спосіб видалення напливів металу в процесі лазерного гравіювання); параметри форми інтагліодруку (спосіб виготовлення (традиційний чи DLE), параметри штрихів форми інтагліодруку (їх ширина, довжина, глибина, відстань між штрихами, вид профілю (трапецієподібний, прямокутний), симетричність профілю (симетричний, асиметричний); параметри процесу вакуумного напилення (температура підложки (форми під час напилення), шорсткість пробільних та друкувальних елементів, товщина нітрид-хромового покриття, режимів травлення підложки в камері напилення, відсотковий склад газової суміші $\mathrm{Ar}-\mathrm{N}_{2}$ в камері напилення).

\section{Список використаних джерел}

1. Kipphan, H. Handbook of Print Media. Technologies and Production Methods. Springer, 2001. $1207 \mathrm{p}$.

2. Pat. US 4966628 A, MПК C09D 11/08. Security document printing ink / Amon, A. etal., Sicpa Holding Sa, Switzerland. US 07/313092; заявл. 21.02.1989; опубл. 30.10.1990. 
3. Kyrychok T. The influence of pressure during intaglio printing on banknotes durability / T. Kyrychok, P. Kyrychok, S. Havenko et al. // Mechanika. 2014. Vol. 20(3). P. 327-331.

4. Pat. US 20120199029 A1, МПК C09D 11/10. Intaglio printing ink / Fukuura A.; National Printing Bureau Incorporated, Japan. 13/501904; заявл. 08.10.2010; опубл. 09.082012.

5. Пат. 006833395 Canada, MПK C09D 11/10; C08L 67/08; C08K 5/16; C08K 5/17. Intaglio printing inks having improved dispersibility and chemical resistance / T. P. Rygas; заявник і патентовласник Canadian Bank Note Company, Limited. заявл. 5.10.2001; опубл. 21.12.2004.

6. Пат. 20100181753 США, MПК G09F 3/00, C09D 11/10, B05D 5/00, B32B 3/10, B42D 15/00, B42D15/10. Intaglio Printing Inks / P. Magnin, P. Degott, S. Chabrier; заявник і патентовласник SICPA Holding S.A.; заявл. 14.07.2008; опублік. 22.07.2008.

7. Pat. CА 2559557A1 Canada, МПК C09D 11/00. Rheologically unique intaglio printing inks / J. Malanga et al.; заявник і патентовласник Sun Chemical Corporation (USA); заявл. 12.03.2004; опубл. 12.09.2006.

8. Lee J. A. Computational study of viscoelastic effects on liquid transfer during gravure printing / J. A. Lee, J. P. Rothstein, M. Pasguali // Journal of NonNewtonian Fluid Mechanics. Elsevier, 2013. Vol. 199. pp. 1-11.

9. Пат. US 20120199029 A1, МПК C09D 11/10. Intaglio printing ink / A. Fukuura; заявник і патентовласник National Prining Bureau Incorporated, Japan; заявл. 08.10.2010; опубл. 09.08.2012.

10. Пат. WO 2013139636 A1, МПК C09D 11/00. Printing method with oxidative-drying intaglio ink and UV-VIS-curable intaglio inks / Deggot, P. et al.; заявник і патентовласник Sicpa Holding Sa, Switzerland; заявл. 23.03.2012; опубл. 26.09.2013.

11. Киричок Т. Ю. Дослідження зміни характеристик зразків банкнот під час імітації зношування / Т. Ю. Киричок, В. М. Нестеренко, Є. Г. Сухіна, О.В.Гуща // Технологія і техніка друкарства. К., 2012. № 4(38). C. 4-25. DOI: https://doi.org/10.20535/2077-7264.4(38).2012.32192.

12. Kimura M. Effect of wax on non-offset property of intaglio ink / M. Kimura, S. Kadono, A. Faruta // J. of Printing Science and Technology. 1988. Vol. 25(3). P. $152-159$.

13. Киричок Т. Ю. Зносостійкість банкнотної продукції: монографія / Т. Ю. Киричок. К.: НТУУ «КПІ», 2014. 308 с.

14. Киричок П. О. Український тлумачний словник видавничо-поліграфічної справи: словник / П. О. Киричок, О. М. Величко, С. Ф. Гавенко, О. В. Зоренко, Т. Ю. Киричок, Т. В. Розум. К.: НТУУ «КПІ», 2010. 896 с.

\section{References}

1. Kipphan, H. (2001). Handbook of Print Media. Technologies and Production Methods. Springer, 1207 p. [in English].

2. Amon, A. etal. Security document printing ink // Patent US 4966628 A. Publish 30.10.1990 [in English].

3. Kyrychok, T. \& Kyrychok, P. \& Havenko, S. et al. (2014). The influence of pressure during intaglio printing on banknotes durability. Journal of Mechanika, Vol. 20(3), 327-331 [in English]. 
4. Fukuura A. Intaglio printing ink // Patent US 20120199029 A1. Publish 09.082012 [in English].

5. T. P. Rygas. Intaglio printing inks having improved dispersibility and chemical resistance // Patent 006833395 Canada. Publish 21.12.2004 [in English].

6. P. Magnin, P. Degott, S. Chabrier. Intaglio Printing Inks // Patent 20100181753 USA. Publish 22.07.2008 [in English].

7. J. Malanga, et al. Rheologically unique intaglio printing inks // Patent CA 2559557A1 Canada. Publish 12.09.2006 [in English].

8. Lee, J. A. \& Rothstein, J. P. \& Pasguali, M. (2013). Computational study of viscoelastic effects on liquid transfer during gravure printing. Journal of NonNewtonian Fluid Mechanics, Vol. 199, 1-11 [in English].

9. A. Fukuura. Intaglio printing ink // Patent US 20120199029 A1. Publish 09.08.2012 [in English].

10. Deggot, P. et al. Printing method with oxidative-drying intaglio ink and UV-VIS-curable intaglio inks // Patent WO 2013139636 A1. Publish 26.09.2013 [in English].

11. Kyrychok, T. Yu. \& Nesterenko, V. M. \& Sukhina, Ye. H. \& Hushcha, O. V. (2012). Doslidzhennia zminy kharakterystyk zrazkiv banknot pid chas imitatsii znoshuvannia. Journal of Tekhnolohiia i tekhnika drukarstva, 4(38), 4-25. DOI: https://doi.org/10.20535/2077-7264.4(38).2012.32192 [in Ukrainian].

12. Kimura, M. \& Kadono, S. \& Faruta, A. (1988). Effect of wax on non-offset property of intaglio ink. Journal of Printing Science and Technology, Vol. 25(3), 152-159 [in English].

13. Kyrychok, T. Yu. (2014). Znosostiikist banknotnoi produktsii. Kyiv: NTUU 'KPI', 308 p. [in Ukrainian].

14. Kyrychok, P. O. \& Velychko, O. M. \& Havenko, S. F. \& Zorenko, O. V. \& Kyrychok, T. Yu. \& Rozum, T. V. (2010). Ukrainskyi tlumachnyi slovnyk vydavnycho-polihrafichnoi spravy. Kyiv: NTUU 'KPI', 896 p. [in Ukrainian].

Современный способ изготовления форм интаглиопечати технология прямого лазерного гравирования (DLE - Direct

Laser Engraving) имеет ряд преимуществ и технологических возможностей по сравнению с традиционной технологией травления, однако, особенности обработки материалов форм лазером и последующего нанесения защитного нитрид-хромового покрытия вакуумным напылением (PVD) могут вызвать снижение тиражестойкости форм по сравнению с традиционными технологиями изготовления форм. Поэтому технология прямого лазерного гравирования с последующим нанесением защитного нитрид-хромового покрытия PVD требует совершенствования режимов гравирования, обработки форм после удаления наплывов и PVD.

Ключевые слова: интаглиопечать; прямое лазерное гравирование; печатные элементы; гравированные штрихи; тиражестойкость; покрытие нитрида хрома; латунь; вакуумное напыление. 
Direct Laser Engraving (DLE) technology is the modern method of manufacturing intaglio printing plates. It has a rank of advantages and technological capabilities compared to traditional etching technology, however, the features of laser processing materials and the subsequent application of protective nitridechromium coating by physical vacuum deposition (PVD) can cause a decrease in the plate run-length compared to traditional etching manufacturing technologies. So direct laser engraving technology with subsequent application of protective nitride-chrome PVD coating needs to be improved in engraving, plate processing for mold removal during and after DLE, and PVD process.

Keywords: intaglio printing; direct laser engraving; space element; printing element; engravings; run-length; nitride-chromium coating; brass; vacuum deposition. 